\title{
RESEARCH ARTICLE \\ Breed Effects on Growth Performance, Blood Parameters and the Levels of Metabolic Hormones in Rabbits Under Heat Stress in Egypt \\ Tamer M. Abdel-Hamid ${ }^{1 *}$ and Ahmed Dawod ${ }^{2}$ \\ ${ }^{1}$ Animal Wealth Development Department, Faculty of Veterinary Medicine, 44511- Zagazig University, Sharkia, Egypt \\ ${ }^{2}$ Department of Husbandry and Animal Wealth Development, Faculty of Veterinary Medicine, University of Sadat City, Menofia, Egypt
}

Article History: Received: 28/03/2020 Received in revised form: 12/05/2020 Accepted: 20/05/2020

\begin{abstract}
This study was constructed to investigate the differences between three breeds of rabbits [New Zealand White (NZW), Rex and Egyptian Gabali (Al-Gabali)] under heat stress regarding growth traits, hematological, biochemical and immunological parameters, oxidative stress biomarkers as well as metabolic hormones. Thirty rabbits of each breed (4 weeks of age) were subjected to heat stress $\left(32 \pm 1^{\circ} \mathrm{C}, 70-80 \%\right.$ relative humidity) in the summer season at the period from mid-July to the end of August 2019. Blood samples were collected at $10^{\text {th }}$ week of age. The results revealed that body weights of NZW and Rex were higher by 205 and $145 \mathrm{~g}$, respectively than those of Al-Gabali as well as average daily gains of NZW and Rex were higher by 4.42 and $3.40 \mathrm{~g} /$ day, respectively compared with Al-Gabali $(P<0.05)$. Average daily feed intake of Rex was lower by $7.65 \mathrm{~g} /$ day than those of NZW and $2.89 \mathrm{~g} /$ day compared with Al-Gabali $(P<0.05)$ and they had the lowest feed to gain ratios (3.58 \pm 0.097$)$. Aspartate aminotransferase, urea and creatinine were significantly lowered in the plasma of Al-Gabali compared with NZW and Rex whereas, Al-Gabali recorded higher total proteins $(5.90 \pm 0.048 \mathrm{~g} / \mathrm{dL})$, total globulins $(2.50 \pm 0.054$ $\mathrm{g} / \mathrm{dL})$, antibody titer against sheep red blood cells $(6.38 \pm 0.111)$ and superoxide dismutase $(7.42 \pm 0.163 \mathrm{IU} / \mathrm{L})$ than NZW $(5.66 \pm 0.069 \mathrm{~g} / \mathrm{dL}, 2.21 \pm 0.084 \mathrm{~g} / \mathrm{dL}, 4.90 \pm 0.068$ and $6.80 \pm 0.053$ IU/L, respectively) and Rex $(5.74 \pm 0.072 \mathrm{~g} / \mathrm{dL} 2.25 \pm 0.095 \mathrm{~g} / \mathrm{dL}, 4.25 \pm 0.095$ and $6.88 \pm 0.050$ IU/L, respectively). Al-Gabali bunnies had higher immunoglobulin $\mathrm{G}$, immunoglobulin A, catalase and glutathione peroxidase than NZW and Rex. However, Al-Gabali recorded the lowest insulin $(15.64 \pm 0.20 \mathrm{ng} / \mathrm{mL})$, growth hormone $(45.80 \pm 0.48 \mathrm{ng} / \mathrm{mL})$ and triiodothyronine $(136.20 \pm 2.15 \mathrm{ng} / \mathrm{mL})$. In conclusion, Al-Gabali rabbits were better adapted to heat stress compared with NZW and Rex, which was reflected in the improvement of health, immunity and oxidative stress indicators as well as lower plasma metabolic hormones, but they didn't have the genetic potential for growth traits.
\end{abstract}

Keywords: Rabbits; growth performance; hematology; oxidative stress; metabolism.

\section{Introduction}

In developing countries, rabbits depicted a lot of advantages as it can be raised in small numbers and in inexpensive cages. They can fill the family needs of fresh meat all over the year. They are raised on a low-cost feeds such as forages, waste fruits and vegetables, as well as byproducts such as corn and rice brans, and their small carcasses are consumed in one or two meals therefore meat storage isn't necessary [1].
Al-Gabali breed is one of the local Egyptian breeds that originated in Sinai, the eastern and western desert of Egypt. It has a yellowishbrown coat color with black hairs in all body parts. It is medium in size and is mainly used for meat production [2]. It is well-adapted to climatic conditions of Egypt for those, it lives in the desert, but now those used for intensive meat production are affected to some extent by climatic conditions as exotic breeds and have body weights near to those of exotic breeds.

*Corresponding author e-mail: (drtamoabha18111980@gmail.com), Animal Wealth Development 
Whilst NZW and Rex are foreign breeds in Egypt and are also medium-sized and used for meat production. The three breeds have a great genetic variation which is of value in crossbreeding programs to get the benefits of hybrid vigor and breed complementarity [3].

Heat stress can be defined as any combination of environmental conditions that cause the environmental temperature to exceed the comfortable zone [4]. Rabbits have no functional sweat glands, produce more heat per kilogram of body weight and the body is covered with dense coat, so heat diffusion in rabbit is difficult [5]. The comfort zone in rabbits is $21^{\circ} \mathrm{C}$, so exposure of rabbits to a higher temperature may bring a heat load on the animal [6]. If the internal body temperature reaches $35^{\circ} \mathrm{C}$, the natural physiological mechanisms of heat loss are no longer functioning and heat prostration occurs [7], and as a result, the normal physiological response of animal is to lower the level of metabolic hormones and enzymes [8].

Rabbit production in the tropics is exposed to a serious problem which is the heat stress as it has a Mediterranean origin and thus, it lacks the adaptability to hot, arid, or humid conditions [1]. Mean body weight, weight gain and feed consumption of rabbit exposed to intense heat stress $\left(29.6^{\circ} \mathrm{C}\right.$ and $75.9 \%$ relative humidity) from 35 to 70 days of age were greatly depressed, and genetic group (purebred Botucatu and crossbreds rabbits) differences have been detected [9]. Lebas and coauthors [10] reported that the same environment may evoke a certain different performance levels in one breed or strain than other and attributed this to differences in the genotype of animals. Breed differences had been reported for blood hematological and biochemical parameters under Egyptian semitropical conditions [11, 12].

Monitoring animal welfare requires an evaluation of plasma oxidative status in farm animals [13]. The animal's ability to maintain homeostasis despite the presence of stressful environmental stimuli is dependent on the results of this assessment [14]. An increase in the production of oxygen-derived free radicals, and consequently oxidative stress could be the result of heat stress [15].

Sheep RBCs (SRBCs) are considered a natural,non-specific, non-pathogenic, multi-det erminant and T-cell- dependent antigen, and thus indicate natural immunity status [16]. The immune response to SRBCs has been evaluated in mice [17], chickens [18] and rabbits [19]. In mammals, the immunoglobulins can be divided into five classes: $\operatorname{Ig} \mathrm{A}, \operatorname{IgD}, \operatorname{IgE}, \operatorname{IgG}$, and $\operatorname{IgM}$, they are differed in the biological properties and the antigen to deal with [20].

The metabolism of carbohydrates, fats, and proteins is controlled by insulin hormone [21]. Insulin and insulin-like growth factor 1(IGF-1) are closely related in their structure and function, involved in feed consumption and cell growth [22]. Cells growth, reproduction, and regeneration in humans and other animals are under the control of growth hormone $(\mathrm{GH})$. It also can result in the release of IGF-1 and elevates the levels of glucose and free fatty acids [23]. There are two thyroid hormones [triiodothyronine $\left(\mathrm{T}_{3}\right)$ and thyroxine $\left(\mathrm{T}_{4}\right)$ ] secreted from thyroid gland. They are mainly concerned with regulation of metabolism. Hence, the measurement of these hormones in different genetic groups under thermal stress may be useful in explaining the difference in the physiological state, which in turn is reflected in the performance of these animals.

In brief, testing three different breeds of rabbits of widely different characteristics and adaptability for growth traits, hematological, biochemical, oxidative stress and immunological parameters as well as blood metabolic hormones had been done in this study.

\section{Materials and Methods}

The current experiment was conducted in the research rabbit unit, Department of Animal Wealth Development, Faculty of Veterinary Medicine - Zagazig University, Egypt during the period from mid-July to the end of August 2019. All experimental procedures were implemented according to the guidelines of the Animal Welfare and Research Ethics Committee (ANWD-206) at the Faculty of Veterinary Medicine, Zagazig University. 


\section{Experimental animals}

This experiment was conducted on thirty male rabbits of three breeds (NZW, Rex and AlGabali). At the beginning of the experiment, the rabbits were four weeks of age and nearly homogenous with average initial body weight of $507 \pm 4.69$ g. Rabbits of each breed were randomly divided into ten replicates (10 cages $(50 \times 50 \times 35 \mathrm{~cm})$; three rabbits per cage $)$. These cages were designed in a flat deck layout, with metal feeders, and an automatic watering system of a drip nipples design (one nipple per cage). Experimental rabbits were ear-tagged and exposed throughout the six-week trial period (from $4^{\text {th }}$ to $10^{\text {th }}$ week of age) to a maximum temperature of $32 \pm 1^{\circ} \mathrm{C}$ and $70-80 \%$ relative humidity. According to the equation of Marai et al. [24], the temperature-humidity index (THI) was calculated: $\mathrm{THI}=\mathrm{dbo} \mathrm{C}-[(0.31-0.31 \mathrm{RH})$ (dbo C - 14.4)], where dbo $C=$ dry bulb temperature in Celsius and $\mathrm{RH}=$ relative humidity percentage/100. THI of more than 29 and less than 30 means severe heat stress.

These rabbits were fed on the pelleted feed (18.4\% crude protein, $12.6 \%$ crude fiber and $12.15 \mathrm{MJ} / \mathrm{kg}$ dry matter digestible energy), which was available for ad-libitum consumption. A fourteen hours photoperiod and a free access to clean water were maintained in this study. A well-ventilated house has been used to house these rabbits and there is a daily hygienic disposal of manure.

\section{Growth traits}

Individual body weights at $4^{\text {th }}$ and $10^{\text {th }}$ weeks of age, and average daily gains (ADG) at 4-8 weeks of age were recorded. Feed intake was calculated on a cage basis and feed to gain ratio was estimated. Feed intake was recorded by subtracting the weight of feed offered per cage and the weight of residual feed per cage then divided by the number of rabbits per cage. Feed to gain ratio was calculated as ratio of between feed intake and weight gain [25].

\section{Hematological and biochemical parameters}

Blood samples were collected from marginal ear vein of each rabbit at $10^{\text {th }}$ week of age and divided into two parts in heparinized test tubes. The first part was used for hematological studies including RBC count according to the method described previously by Coles [26]. Further, hemoglobin $(\mathrm{Hb})$ concentration [27], PCV\% [28], white blood cell (WBC) count [29] and neutrophile and lymphocytes \% [30] were also estimated. However, the other portion was centrifuged at 3500 round per minute (rpm) for 20 min to separate plasma then kept at $-20^{\circ} \mathrm{C}$ for subsequent biochemical and immunological analysis. The following parameters were measured in plasma: total proteins, albumin, total globulins, glucose, cholesterol, triglycerides, alanine aminotransferase (ALT), aspartate aminotransferase (AST), urea and creatinine using commercial kits (Diamond Diagnostics, Holliston, MA, USA).

\section{Immunological parameters}

About 10 rabbits per breed were randomly selected, injected intramuscularly with $0.5 \mathrm{~mL}$ of $10 \%$ suspension of the SRBCs [31], which worked as a T-dependent antigen at $9^{\text {th }}$ week of age. Plasma levels of hemagglutination antibodies against SRBCs were measured at $10^{\text {th }}$ week of age by hemagglutination (HA) test [32] and the antibody titres were measured as $\log _{2}$ values. The enzyme- linked immunosorbent assay (ELISA) test was used to assess the levels of $\operatorname{IgG}, \operatorname{IgM}$ and $\operatorname{IgA}$ in the plasma of injected rabbits with SRBCs.

\section{Oxidative stress biomarkers}

Total antioxidant capacity (TAC) was measured by quantifying the residual of $\mathrm{H}_{2} \mathrm{O}_{2}$ colorimetrically by an enzymatic reaction (Biodiagnostic(C) for diagnostic and research reagents, Dokki, Giza, Egypt) according to the method that was described previously [33]. The antioxidant enzymes such as catalase activity were measured according to Beers and Sizer [34], while glutathione (GSH) [35], glutathione peroxidase (GPx) [36] and superoxide dismutase (SOD) [37] were estimated using RANDOX assay kits (Randox Laboratories, Crumlin, UK).

\section{Plasma metabolic hormones concentrations}

Plasma concentration of IGF-1 was measured using a commercially available ELISA Kit (Rat IGF-1 ELISA Kit, Thermo Scientific). Radioimmunoassay (RIA) technique [38] has been used to measure $\mathrm{GH}$, insulin and $\mathrm{T}_{3}$ plasma concentrations (RIA kits, Tianjin Jiuding Company, China) and a radioactive $\left({ }^{125} \mathrm{I}\right)$ immune $\gamma$ counter was used to measure the radioactivity. Plasma samples from 5 randomly 
selected rabbits were used to measure plasma metabolic hormones concentrations.

\section{Statistical analysis}

The data of growth and blood parameters were analyzed using SAS statistical analysis system package [39]. The following statistical model was utilized (one way ANOVA):

$$
\mathrm{Y}_{\mathrm{ij}}=\mu+\mathrm{B}_{\mathrm{i}}+\mathrm{e}_{\mathrm{ij}}
$$

Where $Y_{i j}=$ measured trait; $B_{i}=$ effect of $i^{\text {th }}$ breed (NZW, Rex and Al-Gabali) and $e_{i j}=$ residual or random error effect. Duncan's multiple range tests [40] has been used for multiple comparison between means at $P<0.05$. Replicate effect has been preliminarily tested and was found to be non-significant. Kolmogorov-Smirnov's test has been used to test the normal distribution of data. The effect of SRBCs within each breed on growth traits has been preliminarily tested and has been found to be non-significant.

\section{Results}

\section{Growth traits}

Referring to the effect of the rabbit breeds on the growth traits, it was found that NZW was the highest in body weight $(1685 \pm 28.71 \mathrm{~g})$ and average daily feed intake (ADFI) $(101.84 \pm 1.00$ $\mathrm{g} / \mathrm{d})$ at ten weeks of age $(P<0.001)$, while AlGabali was the lowest for body weight at ten weeks of age $(1480 \pm 31.09 \mathrm{~g})$ and the Rex occupied a middle place between NZW and AlGabali (1625 $\pm 24.73 \mathrm{~g})$ (Table 1). In the same context, ADG was noticeably affected by the breed, as NZW was the highest at 4-10 weeks of age $(27.76 \pm 0.74 \mathrm{~g} / \mathrm{d} ; P<0.001)$ (Table 1$)$. In contrast, NZW and Rex were the lowest in the feed to gain ratio $(3.74 \pm 0.111$ and $3.58 \pm 0.097)$ compared with Al-Gabali $(4.27 \pm 0.139 ; \quad P$ $<0.001)$ (Table 1).

\section{Hematological parameters}

RBCs, PCV\% and lymphocytes\% were the only hematological parameters that were significantly affected by rabbit breed. The lowest values for the RBCs, as well as the highest values for PCV and lymphocytes \%, were recorded in Al-Gabali $\left(4.13 \pm 0.028 \times 10^{6} / \mathrm{mm}^{3}\right.$, $33.35 \pm 0.764 \%$ and $46.54 \pm 1.049 \%$; respectively), whilst the lowest PCV and lymphocytes\% $\quad(30.40 \pm 0.343 \% \quad$ and $41.35 \pm 0.981)$, as well as the highest RBC $\left(4.46 \pm 0.093 \times 10^{6} / \mathrm{mm}^{3}\right)$ were recorded in Rex (Table 2).

Table 1: Body weights, Average daily gains (ADG), average daily feed intake (ADFI) and feed to gain ratios of heat stressed New Zealand White, Rex and Al-Gabali rabbits

\begin{tabular}{|c|c|c|c|c|}
\hline \multirow{2}{*}{ Variable } & \multicolumn{3}{|c|}{ Breed } & \multirow{2}{*}{$P$-value } \\
\hline & New Zealand White & $\operatorname{Rex}$ & Al-Gabali & \\
\hline \multicolumn{5}{|l|}{ Body weight, $\mathrm{g}$} \\
\hline 4 weeks & $504 \pm 9.68$ & $516 \pm 7.97$ & $499 \pm 6.33$ & 0.322 \\
\hline 10 weeks & $1685 \pm 28.71^{\mathrm{a}}$ & $1625 \pm 24.73^{\mathrm{a}}$ & $1480 \pm 31.09^{\mathrm{b}}$ & $<0.001$ \\
\hline ADG, g/d (4-10 weeks) & $27.76 \pm 0.74^{\mathrm{a}}$ & $26.74 \pm 0.66^{\mathrm{a}}$ & $23.34 \pm 0.73^{\mathrm{b}}$ & $<0.001$ \\
\hline ADFI, g/d & $101.84 \pm 1.00^{\mathrm{a}}$ & $94.19 \pm 0.97^{\mathrm{b}}$ & $97.08 \pm 1.13^{\mathrm{b}}$ & $<0.001$ \\
\hline Feed to gain ratio & $3.74 \pm 0.111^{\mathrm{b}}$ & $3.58 \pm 0.097^{\mathrm{b}}$ & $4.27 \pm 0.139^{\mathrm{a}}$ & $<0.001$ \\
\hline \multirow{2}{*}{\multicolumn{5}{|c|}{$\begin{array}{l}\text { Means } \pm \text { standard errors within the same row having different superscripts are significantly different at } \mathrm{P}<0.05 . \\
\text { Table 2: hematological parameters of heat stressed New Zealand White, Rex and Al-Gabali rabbits }\end{array}$}} \\
\hline & & & & \\
\hline \multirow{2}{*}{ Variable } & \multicolumn{3}{|c|}{ Breed } & \multirow{2}{*}{$P$-value } \\
\hline & New Zealand White & Rex & Al-Gabali & \\
\hline Red blood cells $\left(\times 10^{6} / \mathrm{mm}^{3}\right)$ & $4.36 \pm 0.090^{\mathrm{a}}$ & $4.46 \pm 0.093^{\mathrm{a}}$ & $4.13 \pm 0.028^{b}$ & 0.011 \\
\hline $\mathrm{Hb}(\mathrm{g} / \mathrm{dL})$ & $11.67 \pm 0.192$ & $11.52 \pm 0.053$ & $11.36 \pm 0.103$ & 0.252 \\
\hline $\operatorname{PCV}(\%)$ & $32.45 \pm 0.487^{\mathrm{a}}$ & $30.40 \pm 0.343^{\mathrm{b}}$ & $33.35 \pm 0.764^{\mathrm{a}}$ & 0.001 \\
\hline White blood cells (× 109/l) & $8.54 \pm 0.326$ & $11.45 \pm 2.617$ & $8.73 \pm 0.332$ & 0.330 \\
\hline Neutrophils (\%) & $39.24 \pm 1.266$ & $37.34 \pm 1.011$ & $40.67 \pm 1.123$ & 0.122 \\
\hline Lymphocytes (\%) & $43.70 \pm 1.067^{\mathrm{ab}}$ & $41.35 \pm 0.981^{b}$ & $46.54 \pm 1.049^{a}$ & 0.003 \\
\hline
\end{tabular}

Hb: Hemoglobin concentration; PCV:Packed cell volume. Means \pm standard errors within the same row having different superscripts are significantly different at $P<0.05$. 


\section{Blood biochemical parameters}

The breed effects on blood biochemical parameters were apparent on total proteins, total globulins, albumin/total globulins, AST, urea and creatinine. Al-Gabali had the highest total proteins $(5.90 \pm 0.048 \mathrm{~g} / \mathrm{dL} ; P=0.028)$ and total globulins $(2.50 \pm 0.054 \mathrm{~g} / \mathrm{dL} ; P=0.026)$ plasma concentrations, however, NZW had the lowest values $(5.66 \pm 0.069$ and $2.21 \pm 0.084 \mathrm{~g} / \mathrm{dL}$, respectively) (Table 3 ). The highest levels of AST $(59.22 \pm 1.242 \quad \mathrm{IU} / \mathrm{L} ; \quad P=0.006)$, urea $(23.69 \pm 0.595 \mathrm{mg} / \mathrm{dL} ; P=0.001)$ and creatinine $(0.673 \pm 0.007 \mathrm{mg} / \mathrm{dL} ; P<0.001)$ were recorded in the plasma of NZW while, the lowest levels were observed in Al-Gabali (55.03 $\pm 0.305 \mathrm{IU} / \mathrm{L}$, $21.09 \pm 0.372 \mathrm{mg} / \mathrm{dL}$ and $0.645 \pm 0.001 \mathrm{mg} / \mathrm{dL}$, respectively). Significant lower albumin/total globulins ratios have been calculated in AlGabali (1.38 $\pm 0.037 ; P=0.035$ ) (Table 3).

\section{Immunological parameters}

The plasma levels of IgG, IgA and antibody titre against SRBCs have increased significantly $(3.88 \pm 0.013, \quad 0.492 \pm 0.016 \quad \mathrm{mg} / \mathrm{mL}$ and $6.38 \pm 0.111$, respectively; $P<0.001)$ in Al-Gabali whereas, Rex recorded the lowest levels $(3.44 \pm 0.016, \quad 0.457 \pm 0.002 \mathrm{mg} / \mathrm{mL}$ and $4.25 \pm 0.095)$. No differences $(P=0.654)$ between
NZW, Rex and Al-Gabali rabbits have been detected for plasma IgM concentration (Table 4).

Blood oxidative stress biomarkers and metabolic hormones

Al-Gabali was higher significantly than the NZW and the Rex in relation to catalase, GPx and SOD $(417.47 \pm 4.69, \quad 4.85 \pm 0.024$ and $7.42 \pm 0.163$ IU/L, respectively; $P<0.001)$. NZW had the lowest catalase $(379.16 \pm 4.33 \mathrm{IU} / \mathrm{L})$ and SOD $(6.80 \pm 0.053 \mathrm{IU} / \mathrm{L})$ and Rex was the lowest for GPx $(4.14 \pm 0.033 \mathrm{IU} / \mathrm{L})$. On the other hand, the effects were non-significant on TAC and GSH $(P>0.05)$ (Table 5).

Significant differences $(P<0.05)$ were observed between NZW, Rex and Al-Gabali for metabolic hormones (insulin, $\mathrm{GH}$ and $\mathrm{T}_{3}$ ), where insulin and $\mathrm{GH}$ levels were elevated significantly in NZW rabbits $(16.50 \pm 0.15$ and $49.80 \pm 1.28 \mathrm{ng} / \mathrm{mL}$, respectively), however, in Al-Gabali they decreased significantly $(15.64 \pm 0.20$ and $45.80 \pm 0.48 \quad \mathrm{ng} / \mathrm{mL}$, respectively). Non-significant differences $(P$ $>0.05$ ) were observed between the three breeds for IGF-1 (Table 5). Rex had the highest plasma $\mathrm{T}_{3}$ concentration $(158.20 \pm 0.80 \mathrm{ng} / \mathrm{mL} ; \quad P$ $=0.002$ ), whilst the lowest values were recorded in Al-Gabali (136.20 $\pm 2.15 \mathrm{ng} / \mathrm{mL}$ ) (Table 5).

Table 3: blood biochemical parameters of heat stressed New Zealand White, Rex and Al-Gabali rabbits

\begin{tabular}{|c|c|c|c|c|}
\hline \multirow{2}{*}{ Variable } & \multicolumn{3}{|c|}{ Breed } & \multirow{2}{*}{$P$-value } \\
\hline & New Zealand White & $\operatorname{Rex}$ & Al-Gabali & \\
\hline Total proteins (g/dL) & $5.66 \pm 0.069^{\mathrm{b}}$ & $5.74 \pm 0.072^{\mathrm{ab}}$ & $5.90 \pm 0.048^{\mathrm{a}}$ & 0.028 \\
\hline Albumin (g/dL) & $3.44 \pm 0.034$ & $3.48 \pm 0.039$ & $3.40 \pm 0.023$ & 0.212 \\
\hline Globulin (g/dL) & $2.21 \pm 0.084^{\mathrm{b}}$ & $2.25 \pm 0.095^{\mathrm{b}}$ & $2.50 \pm 0.054^{\mathrm{a}}$ & 0.026 \\
\hline Albumin/globulin & $1.64 \pm 0.092^{\mathrm{a}}$ & $1.67 \pm 0.113^{\mathrm{a}}$ & $1.38 \pm 0.037^{\mathrm{b}}$ & 0.035 \\
\hline Glucose (mmol/L) & $4.86 \pm 0.144$ & $4.84 \pm 0.123$ & $4.78 \pm 0.121$ & 0.884 \\
\hline Cholesterol (mmol/L) & $0.92 \pm 0.007$ & $0.92 \pm 0.006$ & $0.92 \pm 0.006$ & 0.775 \\
\hline Triglycerides (mg/dL) & $16.75 \pm 0.014$ & $16.73 \pm 0.016$ & $16.76 \pm 0.014$ & 0.475 \\
\hline ALT (IU/L) & $68.73 \pm 1.367$ & $66.82 \pm 0.940$ & $65.60 \pm 0.367$ & 0.082 \\
\hline AST (IU/L) & $59.22 \pm 1.242^{\mathrm{a}}$ & $56.97 \pm 0.902^{\mathrm{ab}}$ & $55.03 \pm 0.305^{\mathrm{b}}$ & 0.006 \\
\hline Urea (mg/dL) & $23.69 \pm 0.595^{\mathrm{a}}$ & $22.65 \pm 0.469^{\mathrm{a}}$ & $21.09 \pm 0.372^{b}$ & 0.001 \\
\hline Creatinine (mg/dL) & $0.673 \pm 0.007^{\mathrm{a}}$ & $0.656 \pm 0.004^{b}$ & $0.645 \pm 0.001^{\mathrm{b}}$ & $<0.001$ \\
\hline \multicolumn{5}{|c|}{$\begin{array}{l}\text { ALT: Alanine aminotransferase; AST: Aspartate aminotransferase. Means } \pm \text { standard errors within the same row } \\
\text { having different superscripts are significantly different at } \mathrm{P}<0.05 \text {. }\end{array}$} \\
\hline \multicolumn{5}{|c|}{$\begin{array}{l}\text { Table 4: immunological parameters of heat stressed New Zealand White, Rex and Al-Gabali rabbits using } \\
\text { enzyme-linked immunosorbent assay (ELISA) and hemagglutination (HA) tests. }\end{array}$} \\
\hline \multirow{2}{*}{ Variable } & \multicolumn{3}{|c|}{ Breed } & \multirow{2}{*}{$P$-value } \\
\hline & New Zealand White & $\operatorname{Rex}$ & Al-Gabali & \\
\hline IgG (mg/ml) & $3.66 \pm 0.031^{\mathrm{b}}$ & $3.44 \pm 0.016^{\mathrm{c}}$ & $3.88 \pm 0.013^{\mathrm{a}}$ & $<0.001$ \\
\hline IgM (mg/ml) & $1.05 \pm 0.011$ & $1.06 \pm 0.011$ & $1.03 \pm 0.014$ & 0.348 \\
\hline $\operatorname{IgA}(\mathrm{mg} / \mathrm{ml})$ & $0.480 \pm 0.002^{\mathrm{b}}$ & $0.457 \pm 0.002^{c}$ & $0.492 \pm 0.016^{\mathrm{a}}$ & $<0.001$ \\
\hline Antibody titre (SRBCs) & $4.90 \pm 0.068^{\mathrm{b}}$ & $4.25 \pm 0.095^{\mathrm{c}}$ & $6.38 \pm 0.111^{\mathrm{a}}$ & $<0.001$ \\
\hline
\end{tabular}

IgG: Inmmunoglobulin G; IgM: immunoglobulin M; IgA: immunoglobulin A; SRBCs: sheep red blood cells. Means \pm standard errors within the same row having different superscripts are significantly different at $P<0.05$. 
Table 5: Some blood oxidative stress biomarkers and metabolic hormones of heat stressed New Zealand White, Rex and Al-Gabali rabbits

\begin{tabular}{|c|c|c|c|c|}
\hline \multirow{2}{*}{ Variable } & \multicolumn{3}{|c|}{ Breed } & \multirow{2}{*}{$P$-value } \\
\hline & New Zealand White & $\operatorname{Rex}$ & Al-Gabali & \\
\hline TAC $(\mu \mathrm{m} / \mathrm{L})$ & $470.24 \pm 2.13$ & $467.51 \pm 3.74$ & $464.74 \pm 1.54$ & 0.354 \\
\hline Catalase (IU/L) & $379.16 \pm 4.33^{b}$ & $390.68 \pm 4.60^{\mathrm{b}}$ & $417.47 \pm 4.69^{a}$ & $<0.001$ \\
\hline GSH (mg/dlL) & $18.41 \pm 0.671$ & $18.32 \pm 0.659$ & $18.80 \pm 0.632$ & 0.861 \\
\hline${ }^{3}$ GPX (IU/L) & $4.45 \pm 0.058^{\mathrm{b}}$ & $4.14 \pm 0.033^{c}$ & $4.85 \pm 0.024^{\mathrm{a}}$ & $<0.001$ \\
\hline${ }^{4} \mathrm{SOD}(\mathrm{IU} / \mathrm{L})$ & $6.80 \pm 0.053^{b}$ & $6.88 \pm 0.050^{\mathrm{b}}$ & $7.42 \pm 0.163^{\mathrm{a}}$ & $<0.001$ \\
\hline${ }^{5}$ IGF-1(ng/mL) & $273.40 \pm 11.90$ & $256.80 \pm 19.54$ & $230.00 \pm 5.24$ & 0.114 \\
\hline Insulin $(\mathbf{n g} / \mathbf{m L})$ & $16.50 \pm 0.15^{\mathrm{a}}$ & $16.02 \pm 0.17^{\mathrm{ab}}$ & $15.64 \pm 0.20^{\mathrm{b}}$ & 0.017 \\
\hline Growth hormone (ng/mL) & $49.80 \pm 1.28^{\mathrm{a}}$ & $48.40 \pm 1.02^{\mathrm{ab}}$ & $45.80 \pm 0.48^{\mathrm{b}}$ & 0.041 \\
\hline Triiodothyronine (ng/mL) & $140.20 \pm 5.65^{\mathrm{b}}$ & $158.20 \pm 0.80^{\mathrm{a}}$ & $136.20 \pm 2.15^{\mathrm{b}}$ & 0.002 \\
\hline
\end{tabular}

TAC: Total antioxidant capacity; GSH: Glutathione content; GPX: Glutathione peroxidase; SOD: Superoxide dismutase; IGF-1: Insulin-like growth factor 1. Means \pm standard errors within the same row having different superscripts are significantly different at $\mathrm{P}<0.05$.

\section{Discussion}

The higher growth performance traits (body weight, ADG, ADFI and feed to gain ratio) that have been depicted by exotic breeds (NZW and Rex) compared with local Egyptian breeds (Al-Gabali) were detected in a previous most recent study [41], and this showed the genetic potential of these breeds for growth compared with Egyptian local breed..

Undoubtedly, the growth performance of NZW and Rex in the current study presented a marked deterioration and was certainly lower than those were recorded in earlier findings $[42,43]$, which could be attributed to exposure to relatively higher ambient temperature [9, 44]. On the other hand, the current averages of Al-Gabali rabbits were nearer to those documented previously [2, 45]. In Khalil study [45], $1084 \pm 83$ and $1405 \pm 95 \mathrm{~g}$ for body weight at 8 and 10 weeks of age, respectively; $24 \pm 2.1$ $\mathrm{g} / \mathrm{d}$ for ADG at 5-8 weeks of age and 4.2 \pm 0.24 for feed conversion ratio were documented. Hence, we can conclude that the Egyptian Gabali is adapted to the Egyptian climatic conditions and less susceptible to heat stress compared to foreign breeds. The present results were in agreement with those reported by Khalil and El-Zarie [46]; they found that Saudi Gabali (S) had lower average at all ages studied than Spanish maternal line called Vline $(\mathrm{V})$. The growth performance of NZW was similar to that of Rex except for ADFI ( $P$ $<0.001)$, the NZW was significantly higher than Rex [43].
The non-significant effect of the breed observed in the current study on the WBC count, $\mathrm{Hb}$ concentration, albumin, cholesterol and triglycerides, as well as the significant effect of the breed on the percentage of lymphocytes, total proteins and creatinine were consistent with what was stated in a previous study by Abdel-Hamid and ElTarbany [43]. However, the later authors reported controversy results concerning plasma creatinine level as they found Rex to have higher significant level than NZW (0.66 vs. $0.65 \mathrm{mg} / \mathrm{dL} ; P=0.001)$, but they confirmed the present results with the respect to total proteins, they found Rex to have higher significant values than NZW (5.74 vs.5.52 $\mathrm{g} / \mathrm{dlL} P=0.014)$. It is possible to explain these controversial results to the difference in temperatures at which these experiments were conducted. Differences between NZW and AlGabali had not been detected for hematological and biochemical parameters except for platelet $(P=0.04)$, Al-Gabali was higher than NZW under Al-Qassim, Saudi Arabia environmental conditions $\left(33{ }^{\circ} \mathrm{C} \pm 0.6\right)$ [41]. In another study included two genetics groups (V-line and V-line $\times$ Gabali), it was found that these two genotypes were similar in all blood parameters except for cholesterol, total lipids and triglycerides [47]. Breed differences had been reported for RBCs, $\mathrm{Hb}$ concentration, haematocrit value, total proteins, albumin, globulin, albumin/globulin ratio and triglycerides in a study involved four breeds (Baladi Red, Chinchilla Giganta, 
French Giant Papillon and Simenwar), under Egyptian environmental conditions [48]. Significant genetic group (V-line, Jabali, 1/4 Jabali $\times 3 / 4 \mathrm{~V}$-line and 3/4 Jabali $\times 1 / 4 \mathrm{~V}$-line) effect was detected on cholesterol (69.07, $71.36,144.85$ and $144.60 \mathrm{mg} / \mathrm{dL}$; respectively; $P=0.0008)$, globulin $(2.26,2.26,1.61,2.57$ $\mathrm{g} / \mathrm{dL}$; respectively; $P=0.05$ ) and platelets (114.57, 166.31, 105.92, $75.69 \times 10^{6} / \mathrm{ml}$, respectively; $P=0.02$ ) of growing rabbits under hot environmental conditions $\left(35^{\circ} \mathrm{C} \pm 1\right)$ [12]. Significant breed effect on hematology and blood biochemistry was previously documented [49]. They worked on two imported rabbits (NZW and V-line), and two native rabbits (Baladi Black and Gabali). They also found higher levels of liver enzymes (AST and ALT) in native breeds compared with imported ones, which disagreed with the present results, but their experiment was carried out from September to April (comfortable temperature). Abdel-Hamid and El-Tarbany [43] recorded statistically significant differences with respect to the breed for AST, ALT, urea, Hb concentrations, and $\mathrm{PCV} \%$, but these differences were in interaction with dietary supplement of the bee pollen. With regard to the current results of liver (ALT and AST) and kidney (urea and creatinine) function tests, it is clear that there is a significant improvement in these functions in Al-Gabali compared to other breeds, which reflects the health status, and consequently less exposure to heat stress and this conclusion is reinforced by Marai and coauthors [11] who observed an increase in liver and kidney function tests in male rabbits under Egyptian semitropical climatic conditions. The higher total globulins concentration that has been depicted in Al-Gabali rabbits is indicative of immunity status as the gamma globulin fraction is consists mainly of immunoglobulin so the increase in the immunoglobulin can mainly results in the increase of globulin fraction [50].

Concerning the results of oxidative stress parameters, the current results collaborate those of Abdel-Hamid and Omar [51], who detected significant effect of genetic group on catalase separately and GPx in interaction with dietary supplementation with formic acid under heat stress $\left(32^{\circ} \mathrm{C} \pm 1\right)$. There were nonsignificant effects of breed on TAC, GPx, and malondialdehyde under heat stress [41]. The oxidative stress indicators were recorded in the serum of four exotic rabbit breeds (Fauve de Bourgogne, Chinchilla, British Spot, and New Zealand White) in Ibadan, Southwest Nigeria within July and August, and it was found that the four breeds had similar $(P>0.05)$ serum lipid peroxidation, TAC, catalase, and GPx, whilst British Spot rabbits had a high significant $(P<0.05)$ SOD, which suggests that this breed had the least superoxide anion scavenging ability compared with other breeds [52].

The high levels of catalase and SOD in AlGabali plasma can lead to a decrease in lipid peroxidation compared to NZW and Rex, and this conclusion is consistent with Jimoh et al. [53] in a study on four genetic groups of rabbits under heat stress. The antioxidants (GPx, catalase and SOD) appear to be of great importance in protecting the internal cellular constituents from oxidative destruction [54].

The significant genetic group effect $(P$ $<0.05$ ) on IgG antibody titer to SRBCs had been documented in a study on three rabbit breeds (NZW, V-line and Gabali) and their crosses in Egypt. NZW rabbits had higher significant titer to the first dose $(2.970 \pm 0.013)$ than Gabali (2.910 \pm 0.015$)$, but the titer to the second dose was non-significantly higher in Gabali $(3.150 \pm 0.012)$ than that of NZW (3.110 \pm 0.014$)$ [19]. These contradictory results could be attributed to difference in ambient temperature between this experiment $\left(27^{\circ} \mathrm{C}\right)$ and the current study $\left(32 \pm 1^{\circ} \mathrm{C}\right)$. Also, Abdel-Hamid [55] detected no differences between purebred Californian and Californian $\times$ Rex Crossbreds for IgG serum concentration under the stress of high stocking density. A significant genetic group effect $(P<0.005)$ on immune response with purebreds was higher than crossbreds after $24 \mathrm{~h}$ of phytohemagglutinin $\mathrm{P}$ (PHA-P) injection under heat stress [12].

To our knowledge, the scientific research papers concerning blood metabolic hormones in different breeds of rabbits were scarce 
which made a difficulty in interpreting the current results.

The significant breed effect on plasma insulin concentration in the present study was in agreement with those reported by AbdelHamid and El-Tarbany [43], who detected that Rex rabbit had higher significant values than NZW (Rex, 16.56; NZW, 15.95 ng/mL; $P=0.009)$. They also detected that $\mathrm{T}_{3}$ and IGF1 were somewhat similar in the two genetic groups. Supportive results had been previously published [56]. They found plasma IGF-1, thyroxine, and $\mathrm{T}_{3}$ concentrations unaffected by genotype of pigs (Göttingen Miniature and German Landrace).

The excess of blood glucose is uptaken by the liver, adipose, and muscle tissues under the control of insulin hormone that is secreted by the pancreatic islet beta $(\beta)$ cells. In these organs, it was converted to glycogen with the accumulation of triglyceride in the adipose tissues [57]. Agarwal et al. [58] attributed the significant reduction in the growth of dwarf chickens to deficiency of GH receptors and a lower blood $\mathrm{T}_{3}$ concentration [59].

Numerous hormonal responses can be initiated in warm-blooded species due to heat stress, particularly, the thyroid hormones $\mathrm{T}_{3}$ and $\mathrm{T}_{4}$ [60]. Physiologically, warm-blooded animals react with ambient temperature through control in thyroid hormone secretion. The increase in ambient temperature is associated with the decrease in thyroid hormone secretion and vice versa [61]. A negative linear association between environmental temperature and blood $\mathrm{T}_{3}$ level has been documented in chickens [62]. The lower plasma $\mathrm{GH}$ and $\mathrm{T}_{3}$ concentration in $\mathrm{Al}$ Gabali rabbits indicated that this breed showed better acclimation to heat stress than NZW and Rex and these findings are consistent with those reported by Yousef and Johnson [63], who detected a synergistic effect of decrease in thyroid hormones together with reduction in $\mathrm{GH}$ concentration to reduce heat production. The reduction in GH secretion is very important in acclimation of animals to heat stress because this hormone is calorigenic and activate the thyroid gland so enhances heat production [64]. The low plasma insulin concentration in Al-Gabali is indicative of better acclamation to heat stress, which was supported by a previously published paper [65] in which $33 \%$ reduction in plasma insulin concentration was reported in Holstein cows or Friesian calves due to exposure to high ambient temperature. Finally, the genetic potential of NZW and Rex for growth compared with Al-Gabali and the genetic potential of Al-Gabali for acclimation with hot climate which was reflected in better plasma oxidative status and an improvement in the blood immunity and health indicators, as well as lower plasma metabolic hormones level compared with NZW and Rex is very interesting from the crossbreeding point of view to get the benefits of this mating system such as heterosis and breed complementation [3].

\section{Conclusion}

Al-Gabali rabbits were better adapted to heat stress compared with NZW and Rex, which was reflected in the improvement of health, immunity and oxidative stress indicators as well as lower plasma metabolic hormones, but they didn't have the genetic potential for growth traits. Indeed, these outcomes give a wide area for crossing these breeds in the hope of combining these desired traits in one animal (breed complementarity). Our recommendation is to cross these breeds and test these traits in crossbreds as well as to estimate heterosis and combining ability that will be completed in the future.

\section{Conflict of interest}

The authors declare no conflicts of interest.

\section{References}

[1] McNitt, J.I.; Lukefahr, S.D.; Cheeke, P.R. and Patton, N.M. (2013): Rabbit production, $9^{\text {th }}$ edition. British Library, London, UK: $249 \mathrm{p}$.

[2] Afifi, E.A. (2002): The Gabali Rabbits (Egypt). In Khalil MH, Baselga M (eds). Rabbit genetic resources in Mediterranean countries. Zaragoza: CIHEAM Options Mediterraneennes: Série B. Etudes et Recherches, 38: 55-64.

[3] Safranski, T.J. and Cox, N.M. (2007): Clinical Reproductive Physiology and Endocrinology of Sows: Mating 
Management. In Youngquist, R.S. and Threlfall, W.R. editors. Current Therapy in Large Animal Theriogenology (Second Edition), Saunders WB. 738-749.

[4] Buffington, D.E.; Collazo-Arocho, A.; Canton O.H.; Pitt, D.; Thatcher, W.W. and Collier, R.J. (1981): Black globe-humidity index as comfort equation for dairy cows. Transactions of ASAE, 24: 711-714.

[5] Mou, Y. and Li, S. (1994). Study on the thermal conductivity of rabbit pelts. 1st Int. Conf. Rabbit Prod. In Hot Climate, 6-8 September, 1994, Cario, pp. 489-494.

[6] Habeeb, A. A.; Aboulnaga A.I. and Yousef, H.M. (1993): Influenence of exposure to high temperture on daily gain, feed efficiency and blood components of growing male Californian rabbits. Egyptian J. Rabbit Sci., 3: 73-80.

[7] Lebas, F.; Coudert P.; De Rochambeau H. and Thébault, R.G. (1997): The rabbit husbandry, health and production. Food and Agriculture Organization of the United Nations, FAO, Rome, Italy.

[8] Abdel-Samee, A.M. (1997): Response of New Zealand white rabbits to thermal stress and its amelioration during winter and summer of north Sinai, Egypt. J. Arid Environ., 36: 333-342.

[9] Zeferino, C.P.; Moura, A.S.A.M.T.; Fernandes, S.; Kanayama, J.S.; Scapinello, C. and Sartori, J.R. (2011): Genetic group $\times a m b i e n t$ temperature interaction effects on physiological responses and growth performance of rabbits. Livest. Sci., 140(1-3): 177-183.

[10] Lebas, F.; Coudert, P.; Rochambeau, H. and Thebault, R.G. (1996): El conejo: cria y patologia. Colección FAO. Produccion y sanidad animal. Organizacion de las Naciones Unidas para la Agricultura y la Alimentacion, Roma.

[11] Marai, I.; Habeeb, A. and Gad, A. (2003): Reproductive traits of male rabbits as affected by climatic conditions, in the subtropical environment of Egypt. J. Anim. Sci., 77: 451-458.

[12] Fathi, M.; Abdelsalam, M.; Al-Homidan, I.; Ebeid, T.; El-Zarei, M. and Abou-Emera, O. (2017): Effect of probiotic supplementation and genotype on growth performance, carcass traits, hematological parameters and immunity of growing rabbits under hot environmental conditions. Anim. Sci. J., 88(10): 1644-1650.

[13] Vassalle, C. (2009): An easy and reliable automated method to estimate oxidative stress in the clinical setting. In: Armstrong, D. editor. Advanced protocols for oxidative stress I. In methods in molecular biology series. New York: Humana Press, 477: 3139.

[14] Chirase, N.K.; Greene, L.W.; Purdy, C.W.; Loan, R.W.; Auvermann, B.W.; Parker, D.B.; Walborg, E.F.Jr.; Stevenson, D.E.; $\mathrm{Xu}$, Y. and Klaunig, J.E. (2004): Effect of transport stress on respiratory disease, serum antioxidant status, and serum concentrations of lipid peroxidation biomarkers in beef cattle. American Journal of Veterinary Research, 65(6): 860-864.

[15] Liu, H.W.; Dong, X.F.; Tong, J.M. and Zhang, Q. (2011): A comparative study of growth performance and antioxidant status of rabbits when fed with or without chestnut tannins under high ambient temperature. Anim. Feed Sci. Tech., 164(1-2): 89-95.

[16] Pinard, M.H.; Van Arendonk, J.A.M.; Nieuwland, M.G.B. and Van der Zijpp, A.J. (1992): Divergent selection for immune responsiveness in chickens: estimation of realized heritability with an animal model. J. Anim. Sci., 70(10): 2986-2993.

[17] Biozzi, G.; Asofsky, R.; Lieberman, R.; Stiffel, C.; Mouton, D.; and Benacerraf, B. (1970): Serum concentration and allotypes of immunoglobulins in two lines of mice genetically selected for high'or low'antibody synthesis. J. Exp. Med., 132(4): 752-764.

[18] Van der Zijpp, A.J.; Frankena, K.; Boneschanscher, J. and Nieuwland, M.G.B. (1983): Genetic analysis of primary and secondary immune responses in the chicken. Poult. Sci. J., 62(4): 565-572.

[19] El-Tarabany, M.S. and El-Bayoumi, Kh.M. (2010): Effects on some immunological traits after crossing three rabbit breeds in Egypt. Vet. Ital., 46(3): 345-351.

[20] Pier, G.B.; Lyczak, J.B. and Wetzler, L.M. (2004): Immunology, Infection, and Immunity. Washington, ASM Press. ISBN 1-55581-246-5. 
[21] Stryer, L. (1995): Biochemistry, 4th edition. New York: W.H. Freeman and Company. 773-74.

[22] Rinderknecht, E. and Humbel, R.E. (1978): The amino acid sequence of human insulinlike growth factor I and its structural homology with proinsulin. J. Biol. Chem., 253: 2769-2776.

[23] Ranabir, S. and Reetu, K. (2011): "Stress and hormones". Indian J. Endocrinol. Metab., 15(1): 18-22.

[24] Marai, I.F.M.; Abdel-Samee, A.M. and ElGafaary M.N. (1991): Criteria of response and adaptation to high temperature for reproductive and growth traits in rabbits. Options Mediterraneennes-Serie Siminarires, 17: 127-134.

[25] Attia, Y.A.; Hamed, R.S.; Abd El-Hamid, A.E.; Al-Harthi, M.A.; Shahba, H.A. and Bovera, F. (2014): Performance, blood profile, carcass and meat traits and tissue morphology in growing rabbits fed mannanoligosaccharides and zinc-bacitracin continuously or intermittently. Anim. Sci. Pap. Rep., 33(1): 85-101.

[26] Coles, E.H. (1986): Veterinary Clinical Pathology, $4^{\text {th }}$ edition. W.B. Saunders Company, Philadelphia, 17-19.

[27] Singh, K. (1983): Effect of heat stress on blood constituents in crossbred heifers. Indian J. Anim. Sci., 53: 355-357.

[28] Wintrobe, M.M. (1981): Principles of hematologic examination. In: Wintrobe MM. editor. Clinical hematology, 8th edition, Philadelphia: Lea \& Febiger, 7-19.

[29] Cline, M.J. and Hutton, J.J. (1983): Hematology and oncology. In: Stein, J.H. editor. Internal Medicine, Boston, Little, Brown.

[30] Lucky, Z. (1977): Methods for the diagnosis of fish diseases, Ameruno Publishing Co, PVT, LTd. New Delhi, Bomby, New York, $140 \mathrm{p}$.

[31] Van der Zijpp, A.J.; Scott, T.R. and Glick, B. (1986): The effect of different routes of antigen administration on the humoral immune response of the chick. Poult. Sci. J., 65(4): 809-811.

[32] Prescott, J.; Lastra, M. and Barksdale, L. (1982): Equi factors in the identification of
Corynebacterium equi Magnusson. J. Clin. Microbiol., 16(5): 988-990.

[33] Koracevic, D.; Koracevic, G.; Djordjevic, V.; Andrejevic, S. and Cosic, V. (2001): Method for the measurement of antioxidant activity in human fluids. J. Clin. Pathol., 54(5): 356-361.

[34] Beers, R.F and Sizer, I.W. (1952): A spectrophotometric method for measuring the breakdown of hydrogen peroxide by catalase. J. Biol. Chem., 195(1): 133-140.

[35] Beutler, E.; Duron, O. and Kelly, B.M. (1963): An improved method for the detection of blood glutathione. J. Lab. Clin. Med., 61: 882-888.

[36] Chiu, D.T.Y.; Stults, F.H. and Tappel, A.L. (1976): Purification and properties of rat lung soluble glutathione peroxidase. Biochim. Biophys. Acta., 445(3): 558566.

[37] Misra, H.P. and Fridovich, I. (1972): The role of superoxide anion in the autoxidation of epinephrine and a simple assay for superoxide dismutase. J. Biol. Chem., 247(10): 3170-3175.

[38] Chu, F.S. (2003): Immunoassays | Radioimmunoassay and Enzyme Immunoassay. In Caballero, B. Editors. Encyclopedia of Food Sciences and Nutrition (Second Edition), Academic Press, 3248-3255.

[39] SAS, (2008): Statistics Analysis System users Guide, (Release 9.2), SAS Institute Inc., Cary, North Carolina, USA.

[40] Duncan, D.B. (1955): The Multiple Range and F. Tests. Biometrics, 11:1-45.

[41] Abdelsalam, M.; Al-Homidan, I.; Ebeid, T.; Abou-Emera, O.; Mostafa, M.; Abd ElRazik, M.; Shehab-El-Deen, M.; Abdel Ghani, Sh. and Fathi, M. (2019): Effect of silver nanoparticle administration on productive performance, blood parameters, antioxidative status, and silver residues in growing rabbits under hot climate. Animals (Basel), 9(10): 845.

[42] Nasr, M.A.F.; Abd-Elhamid, T. and Hussein, M.A. (2017): Growth performance, carcass characteristics, meat quality and muscle amino acid profile of different rabbits breeds and their crosses. Meat Sci., 134: 150-157. 
[43] Abdel-Hamid, T.M. and El-Tarabany, M.S. (2019): Effect of bee pollen on growth performance, carcass traits, blood parameters, and the levels of metabolic hormones in New Zealand White and Rex rabbits. Trop. Anim. Health. Prod., 51(8): 2421-2429.

[44] Abdel-Hamid, T.M. and Farahat, M.H. (2016): Effect of dietary mannanoligosaccharides on some blood

biochemical, hematological parameters and carcass traits in purebred New Zealand White and crossbred rabbits. Anim. Prod. Sci., 56(12): 2133-2139.

[45] Khalil, M.H (1999): Rabbit genetic resources of Egypt. Anim. Genet. Resour. Inf., 26: 95-111.

[46] Khalil, M.H. and El-Zarie, M.F. (2012): Genetic groups comparisons for growth, carcass, meat quality and blood parameters in program of synthesizing new lines of rabbits. Proceedings $10^{\text {th }}$ World Rabbit Congress, September 3-6, Sharm El-Sheikh, Egypt $241-245$.

[47] Al-Dobaib, S.N.; Khalil, M.H.; Hashad, M. and Al-Saef, A.M. (2007): Growth, carcass and caecal traits in V-Line and crossbred rabbits fed diets containing discarded dates. World Rabbit Sci., 15(2): 81- 90.

[48] Abdel-Azeem, A.S.; Abdel-Azim A.M.; Darwish, A.A. and Omar, E.M. (2010): Haematological and biochemical observations in four pure breeds of rabbits and their crosses under Egyptian environmental conditions. World Rabbit Sci., 18(2): 1 - 8.

[49] El-Sheikh, T.M.; Mona, M.Gh. and Selem, T.S.T. (2011): Comparative studies on some productive capabilities among imported, endogenous and native rabbit breeds under Egyptian environmental conditions. Lucrări Ştiinţifice-Universitatea de Ştiinţe Agricole şi Medicină Veterinară, Seria Zootehnie, 56: 364-369.

[50] Busher, J.T. (1990): Serum Albumin and Globulin. In: Walker, H.K.; Hall, W.D. and Hurst, J.W. editors. Clinical Methods: The History, Physical, and Laboratory Examinations. 3rd edition. Boston: Butterworths, Chapter 101. Available from: https://www.ncbi.nlm.nih.gov/books/NBK2 $\underline{04 /}$
[51] Abdel-Hamid, T.M. Omar, M.A. (2019): Growth and economic performance, some hematological, biochemical and oxidative stress parameters, and carcass traits of summer stressed Californian and crossbred rabbits as affected by dietary supplementation of formic acid. Slov. Vet. Res., 56 (Suppl 22): 707-716.

[52] Jimoh, O.A. (2019): Oxidative stress indicators of rabbit breeds in Ibadan, Southwest Nigeria. Bull. Natl. Res. Cent., 43: 62.

[53] Jimoh, O.A.; Ewuola, E.O. and Balogun, A.S. (2017): Oxidative Stress Markers in Exotic Breeds of Rabbit during Peak of Heat Stress in Ibadan, Nigeria. Journal of Advances in Biology \& Biotechnology, 12(1): 1-9.

[54] Bagchi, D. (Ed.), Preuss, H., Swaroop, A. (Eds). (2016): Nutraceuticals and Functional Foods in Human Health and Disease Prevention. Boca Raton: CRC Press.

[55] Abdel-Hamid, T.M. (2018): Effect of stocking density on growth performance, some blood parameters and carcass traits in purebred Californian and crossbred rabbits. J. Adv. Vet. Anim. Res., 5(3): 265-274.

[56] Elsaesser, F.; Pfaffl, M.W.; Meyer, H.H.D.; Serpek, B. and Sauerwein, H. (2002): Differences in the somatotropic axis, in blood cortisol, insulin and thyroid hormone concentrations between two pig genotypes with markedly divergent growth rates and the effects of growth hormone treatment. J. Anim. Sci., 74(3): 423-430.

[57] Scanes, C.G. (2011): Hormones and Metabolism in Poultry. In Aimaretti, G.; Marzullo, P. and Prodam, F. editors. Update on Mechanisms of Hormone Action-Focus on Metabolism, Growth and Reproduction. ISBN: 978-953-307-341-5, InTech, 111-132. Available from: http://www. intechopen.com/books/updateon-mechanisms- of-hormone-actionfocuson- metabolism-growth-andreproduction/ hormones- and-metabolismin- poultry.

[58] Agarwal, S.K.; Cogburn, L.A. and Burnside, J. (1994): Dysfunctional growth hormone receptor in a strain of sex-linked dwarf chickens: evidence for a mutation in 
the intracellular domain. J. Endocrinol., 142(3): 427-434.

[59] Scanes, C.G.; Marsh, J.; Decuypere, E. and Rudas, P. (1983): Abnormalities in the plasma concentration of thyroxine, triiodothyronine and growth hormone in sex-linked dwarf and autosomal dwarf white leghorn domestic fowl (Gallus domesticus). J. Endocrinol., 97(1): 127-135.

[60] Chiang, W.; Booren, A. and Strasburg, G. (2008): The effect of heat stress on thyroid hormone response and meat quality in turkeys of two genetic lines. Meat Sci., 80(3): 615-- 622.

[61] Silva, J.E. (2003): The thermogenic effect of thyroid hormone and its clinical implications. Ann. Intern. Med., 139: 205213.

[62] Tao, X.; Zhang, Z.Y.; Dong, H.; Zhang, H. and Xin, H. (2006): Responses of thyroid hormones of market-size broilers to thermoneutral constant and warm cyclic

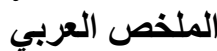

تاثير السلالة على أداء النمو، بعض أثكال الام، والكيمياء الحيوية، والمناعة، والأكسدة وهرمونات التمثيل الغذائي في

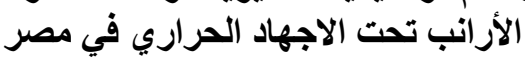

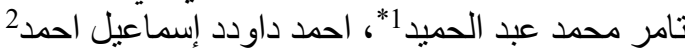

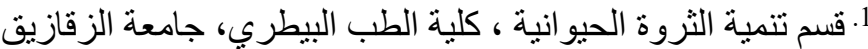

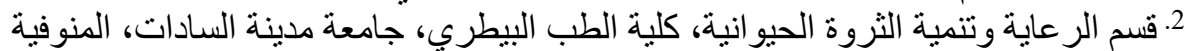

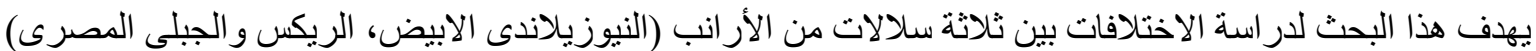

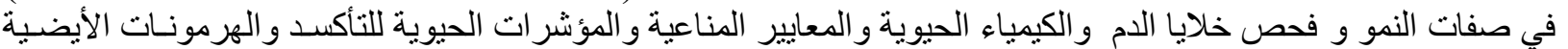

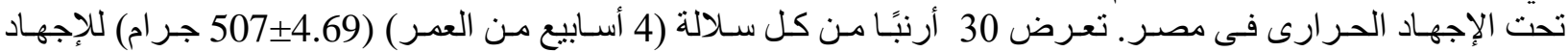

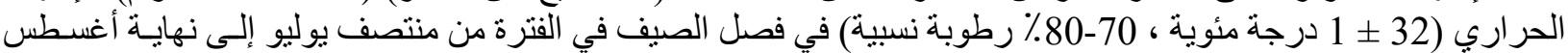

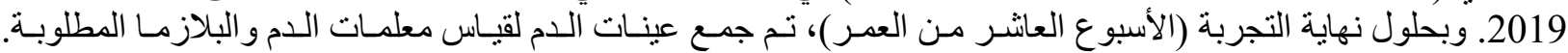

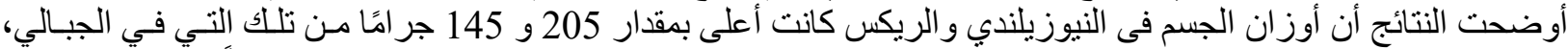

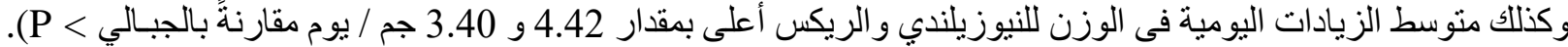

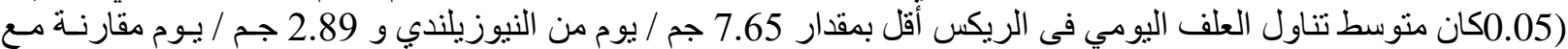

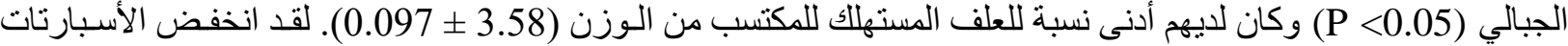

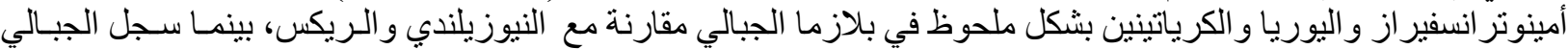

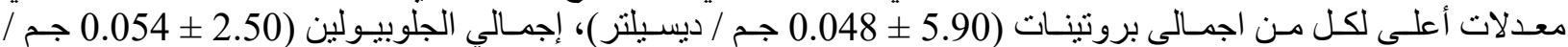

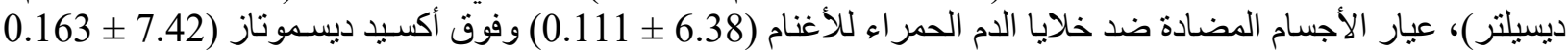

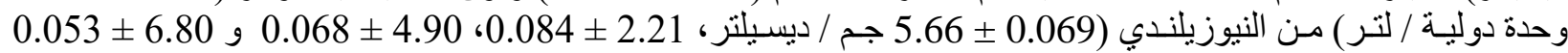

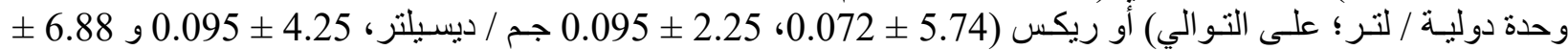

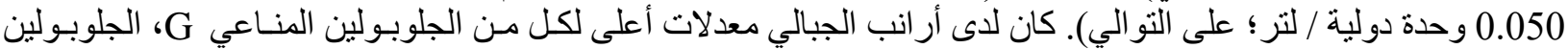

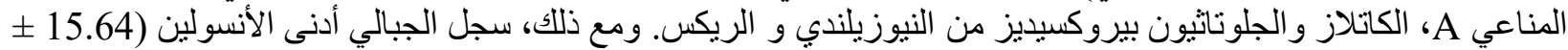

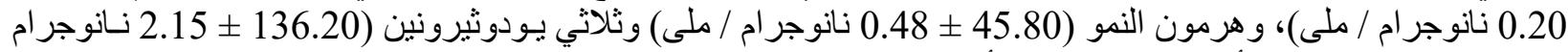

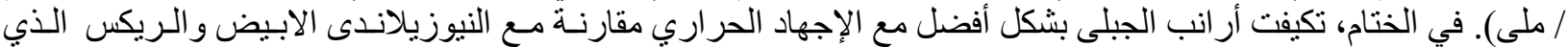

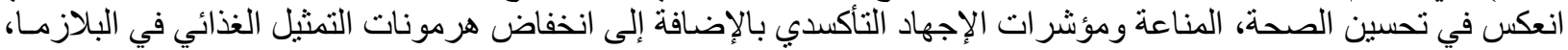

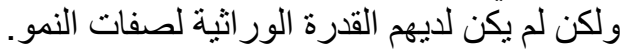

